\title{
Long-chain diesters of fattyy alcohols as novel phase change materials for thermal energy storage
}

\author{
Derya KAHRAMAN DÖĞ̈̈ŞC ${ }^{1 *(1 D)}$ \\ ${ }^{1}$ Tokat Gaziosmanpaşa University, Department of Chemistry 60250, Tokat, Turkey
}

\begin{abstract}
In this study, long chain diesters of fatty alcohols were synthesized for use in thermal energy storage applications. Long-chain diesters of adipic acid were proposed for the first time in this study to be used as phase change material (PCM). For this purpose, ditetradecyl adipate (DTA) and dioctadecyl adipate (DOA) were synthesized as novel solid-liquid PCMs by means of the direct esterification reaction of adipic acid with 1-tetradecanol and 1-octadecanol. The reaction was yielded at around $90 \%$ as an average at the end of 6 hours. The DTA and DOA were characterized chemically using FT-IR and 1HNMR techniques as the energy storage properties, total enthalpy, and specific heat $(\mathrm{Cp})$ capacity values were determined by DSC analysis. Melting temperatures and enthalpies of DTA and DOA were measured as 44 and 60

$\checkmark$ C respectively; and 142.4 and $186.2 \mathrm{Jg}-1$ respectively. Total enthalpy calculation showed the latent heat storage capacity along with sensible heat capacity of fatty alcohols and longchain diesters between 0 and $80 \square \mathrm{C}$. Cp values of fatty alcohols and long-chain diesters also calculated for solid and liquid phase separately. TGA analysis was performed to determine thermal stability of the esters. DTA and DOA compounds were found stable up to 248.3 and $342.5 \square$ C respectively. Thermal cycling test was applied to the materials and it was found that DTA and DOA are both found stable after 1000 times accelerated thermal cyclings. According to the results obtained, DTA and DOA with high energy storage capacity are promising to be used as new solid-liquid PCMs in thermal energy storage applications for medium temperature applications
\end{abstract}

\section{Article info \\ History:}

Received:02.01.2020

Accepted:31.01.2020

Keywords:

Thermal energy

storage,

Phase change

materials,

Adipic acid,

Fatty alcohols.

\section{Introduction}

With the rapid increase in industry, economy and population, the risk of extinction of fossil fuels, increased carbon emissions and rapid growth of global warming based on fossil energy sources, most importantly the inevitable gap between energy resources and energy needs are directed researchers to find a renewable, clean energy, and efficient use of energy sources [1-4]. The way of reduce energy consumption and environmental pollution from consumptions to use energy more effectively. Although thermal energy storage (TES) cannot be considered as a one of the main sources of energy in the industry, it has been rapidly developing in recent years due to the assessment of waste heat in the industry, the ability to regulate when other sources are interrupted and offer an alternative to fossil resources etc. [5]. Also TES is not only eliminates the problem of variable and intermittent character of renewable energy sources, but also reduce internal temperature fluctuations and increases comfort [6].

Thermal energy can be stored in different forms such as sensible, latent, chemical reaction or combination of them [7,8]. TES materials using phase change materials (PCMs) are the most efficient and useful ways to storage energy compared to other alternatives $[9,10]$. PCMs, so called latent heat storage materials can store or release high amount of energy with no or very small volume change during phase transition in small temperature ranges $[11,12]$.

PCMs have very large energy densities compared to sensible heat storage as they had about 5 times lower energy density than chemical reaction energy. However, efficient cost and lower complexity make PCMs more practical than chemical reaction energy [13-15]. PCMs can be classified to two main groups: inorganic and organic. Despite the superior properties of inorganic PCMs, salt hydrates, such as high melting enthalpy, high thermal conductivity and low price, the handicaps like non-reversible phase transformation, 
high supercooling behavior, corrosion and phase separation severely restrict their availability in TES systems [16,17]. Therefore, organic PCMs with better chemical and thermal resistance are more preferred in TES systems. Lots of organic PCMs have been studied as PCMs as Table 1 shows the properties of some organic PCMs in the literature. In addition to phase change enthalpy and temperature of PCMs, it is necessary to determine some other characteristic like thermal conductivity, specific heat capacity, service life, corrosivity, and flammability prior to use in TES systems $[8,18,19]$.

Table 1. Some organic compounds and their TES properties in the literature

\begin{tabular}{|c|c|c|c|c|}
\hline Compound & & $\begin{array}{l}\text { Melting } \\
\text { Temperatu } \\
\text { re }\left({ }^{\circ} \mathrm{C}\right)\end{array}$ & $\begin{array}{l}\text { Freezing } \\
\text { Temperatu } \\
\text { re }\left({ }^{\circ} \mathrm{C}\right)\end{array}$ & $\begin{array}{l}\text { Latent heat } \\
\text { capacity } \\
\text { (heating and } \\
\text { cooling } \\
\text { respectively, } \mathrm{Jg}^{-} \\
\text {1) }\end{array}$ \\
\hline \multirow[t]{5}{*}{ Paraffins } & n-heptadecane [20] & 21.4 & 21.4 & 216.4 and -214.0 \\
\hline & n-octadecane [20] & 27.8 & 24.6 & 226.2 and -224.0 \\
\hline & n-nonadecane $[20]$ & 31.5 & 31.5 & 230.8 and -223.8 \\
\hline & n-eicosane [21] & 34.6 & 33.4 & 242.8 and -244.5 \\
\hline & n-tetracosane [20] & 50.1 & 50.1 & 275.0 and -243.5 \\
\hline \multirow[t]{4}{*}{ Fatty acids } & stearic acid [22] & 60.9 & 66.4 & 242.2 and -246.7 \\
\hline & palmitic acid [22] & 60.5 & 59.9 & 221.4 and -226.6 \\
\hline & myristic acid [22] & 52.4 & 52.5 & 210.7 and -212.7 \\
\hline & lauric acid [22] & 42.1 & 42.2 & 190.1 and -194.2 \\
\hline \multirow{4}{*}{$\begin{array}{l}\text { Fatty } \\
\text { alcohols }\end{array}$} & dodecanol [23] & 22.8 & & 207.3 and -206.2 \\
\hline & tetradecanol [24] & 35.9 & 32.3 & 236.1 and -234.5 \\
\hline & hexadecanol [25] & 48.4 & 47.2 & 248.1 and -232.1 \\
\hline & octadecanol [26] & 59.1 & 55.6 & 246.0 \\
\hline \multirow{5}{*}{$\begin{array}{l}\text { Eutectic } \\
\text { mixtures }\end{array}$} & stearic acid-benzamide [27] & 67.9 & & 200.3 \\
\hline & $\mathrm{Na}_{2} \mathrm{SO}_{4} \cdot 10 \mathrm{H}_{2} \mathrm{O}-\mathrm{KCl}[28]$ & 33.1 & 16.3 & 249.4 \\
\hline & n-tetracosane-n-octadecane & 25.9 & 25.9 & 242.6 and -238.5 \\
\hline & [29] & 24.7 & 27.1 & 163.5 and -158.9 \\
\hline & palmitic-capric acid [30] & & & \\
\hline \multirow[t]{3}{*}{ Esters } & pentyl valerate [31] & 14.1 & & 173.4 \\
\hline & myristyl myristate [31] & 44.5 & & 193.8 \\
\hline & lauryl behenate [31] & 54.5 & & 185.2 \\
\hline \multirow[t]{4}{*}{ Polymers } & $\begin{array}{l}\text { Poly(ethylene glycol) } \\
\text { (PEG) } 1000[32]\end{array}$ & 44.2 & & 163.3 \\
\hline & PEG $3400[32]$ & 63.0 & & 191.7 \\
\hline & PEG 10000 [32] & 66.0 & & 188.7 \\
\hline & PEG 20000 [32] & 68.5 & & 177.4 \\
\hline
\end{tabular}

Paraffin waxes and fatty acids which are most commonly used TES materials for their relatively high enthalpy, low supercooling, and corrosivity, although that the melting point is in limited range, they are flammable and they are costly [31]. It is expected that the carboxylic acid esters have similar thermal properties with the paraffins due to their structural similarity. However, there are not enough studies on the evaluation of esters as PCM.

Carboxylic esters are polarized structures that are formulated as R-COOR' with C-O double bonds in their structures. The degree of polarization is high due to the electro negativity difference between oxygen and carbon atoms. The polarization degree and chain length of the esters change the reactivity of the material. That is, as the chain length increase, the reactivity of the materials decreases. They are generally synthesized from alcohols and carboxylic acids by simple experimental procedures, strong acid catalytic reaction named Fisher esterification or alcoholysis. However, the reaction yield is low if the water generated during the reaction must is not removed from the medium. In this study, the esters were produced under vacuum, solvent free and without catalyst in high yield by using the method of synthesis 
of Baykut et al. [33]. The previously produced esters have high latent heat capacity, low overcooling degree and great thermal reliability after accelerated thermal cycles [33].

There is limited information of esters for their thermal properties to be validated as PCMs. The studies in the literature are about the characterization of existing organic esters as phase change labeling and increasing their thermal performance or synthesizing new esters from fatty acids and fatty alcohols as PCMs. Parameshwaran et al. were investigated thermal properties of silver nano-based organic ester. They declared that ethyl cinnamate embedded with silver nano particles produced melting enthalpy ranging from 93.32-86.69 $\mathrm{Jg}^{-1}$ and reduced degree of supercooling degree by $11.7-6.8 \%$ [34]. Wi et al. examined the thermal properties of organic fatty acid esters with exfoliated graphite nanoplatelets particles. The thermal conductivity of the shape-stabilized PCMs was increased by $414 \%$ and $437 \%$ by the nanometal particles bound to palm oil and coconut oil using the vacuum impregnation method [35]. Aydın presented commercial products, which are widely used in personal care and cosmetics industry, with phase change enthalpies and temperatures, specific heat capacity values, and thermal reliability after 1000 accelerated thermal cycling [36]. Feldman et al. produced $20-21 \%$ butyl stearate added gypsum wallboard which can store energy thermally. The produced panel had 10 fold of the energy store capacity of the panel without PCM. Also, they had a very good mechanical strength [37]. Stamatio et al. identified thermophysical properties of commercial unbrached and saturarated carboxylic esters both by experimental measurement as well as literature research [31]. In the literature, esters synthesized for the first time to store thermal energy have a very high energy storage capacity. Feldman et al. synthesized 12 low chain esters by esterification of methyl, butyl, and propyl alcohols with palmitic and stearic acids. They characterized a range of PCMs with a melting temperature in the range of $17-34{ }^{\circ} \mathrm{C}$ and a storage capacity of 140-190 $\mathrm{Jg}^{-1}$ [38]. Sar1 et al. have synthesized many different fatty acid esters $[39,40]$. The synthesized esters are structurally and thermally characterized. In a study, myristic, palmitic and stearic acid with glycerol were converted to fatty acid esters by Fisher esterification. They produced 3 new esters with melting temperatures ranging from 31.96-63.45 ${ }^{\circ} \mathrm{C}$ and melting enthalpy of $149.4-185.9 \mathrm{Jg}^{-1}$. The thermal conductivity of the produced solid-liquid PCMs was increased by $12-42 \%$ with the addition of $5 \mathrm{wt} \%$ expanded graphite [39]. In another study, Sar1 et al. produced a series of stearic acid esters by reacting stearic acid with n-butyl alcohol, isopropyl alcohol, and glycerol and characterized by using FT-IR and ${ }^{1}$ HNMR analysis. Thermal properties of PCMs were determined by DSC measurement before and after 1000 thermal cycles [40]. Sar1 et al. also produced ester-based composites from synthesized esters with diatomite, vermiculite and expanded perlite $[41,42]$. Kahraman Döğüşcü also has synthesized long chain diesters using different diacids. Dicarboxylic acid esters have produced direct esterification reaction of oxalic acid [43] or succinic acid [44] with 1tetradecanol and 1-octadecanol. Another study, Aydin ve Okutan prepared 3 different polyurethane-PCM composite by polymerizing the polyol, silicon, catalyst and different amounts of PCM mixture with polymeric methylene diisocyanate. While the heat capacity of polyurethane was determined to be improved by $34 \%$ by DSC analysis, the particle size distribution of the PCM in the foam was determined by an optical microscope and a scanning electron microscope [45]. Studies on microencapsulation of fatty acid esters are also available in the literature. Aydın microencapsulated commercial ester product of BASF, Cetiol MM, in poly (urethane-urea) shell material by using amino alcohol [46].

Although fatty alcohols have high heat storage capacity, they do not have much application area due to their low stability. For this reason, fatty alcohols can usually be functionalized and used in TES systems. Esters are very suitable for TES applications due to their chemical and thermal stability. However, there are not many studies on esters in the literature. Therefore, in this study, fatty acid diesters of adipic acid were synthesized for the first time in the literature for TES systems due to the advantages of esters for chemical and thermal energy storage. All reactions cared out solvent free condition and under vacuum. In comparison to traditional Fisher esterification, used synthetic method overcome water removal problem which occur as a byproduct at the end of the reaction. The used method also eliminates the problem of removing water, which significantly reduces reaction efficiency in the fisher esterification method.

\section{Materials and Methods}

\subsection{Materials}

Dicarboxylic acid esters were synthesized using adipic acid (Sigma, 99\%), 1-tetradecanol (Aldrich, 97\%) and 1-octadecanol (Aldrich, +99\%) as received without further purification. Ethanol (Merck, +99.5\%) and acetone (Merck, +99.8\%) were used for the purification of the final product. 


\subsection{Synthesis}

Synthesis of long-chain diesters in question were performed by esterification reaction of adipic acid together with 1-tetradecanol and 1-octadecanol under 2-3 $\mathrm{mmHg}$ vacuum without using acid catalyst and any solvent in place of acid-catalyzed Fischer esterification method [33]. 1-tetradecanol or 1-octadecanol was used excessive to adipic acid in two-necked conical flask. After the reagents reached the melting temperatures, flask was connected to a vacuum motor and the reaction was started. Then rxn was conducted at 130$140{ }^{\circ} \mathrm{C}$ by mixing with a magnetic stirrer for 6 hours. At the end of the reaction, a white solid material was purified with ethanol and acetone to remove fatty alcohol and diacids residuals. A schematic representation of the reaction with efficiency over $90 \%$ was shown in Figure 1.

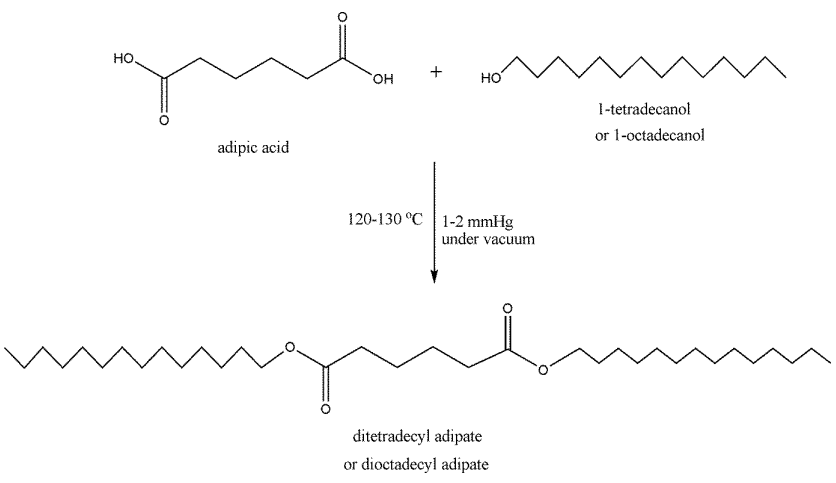

Figure 1. The synthetic scheme of the long-chain diesters

\subsection{Characterization}

\subsubsection{Chemical characterizations}

The chemical characterization of long-chain diesters were performed by Fourier transform infrared (FT-IR) spectroscopy and nuclear magnetic resonance $\left({ }^{1}\right.$ HNMR) spectroscopic techniques. For the FT-IR analyses, Jasco FT-IR-4700 with ATR accessory spectrophotometer was used between 4000 and 400 $\mathrm{cm}^{-1}$. The resolution of the spectra and number of scan were adjusted as $4 \mathrm{~cm}^{-1}$ and 16 , respectively. AVANCE III $400 \mathrm{MHz}$, Bruker model NMR was employed as another structural characterization method. The ${ }^{1} \mathrm{HNMR}$ analyses were realized using $\mathrm{CDCl}_{3}$ solvent and tetramethylsilane as an internal reference standard.

\subsubsection{Thermal characterizations}

Thermal properties such as phase change enthalpy, melting and solidification temperature, total enthalpy, and specific heat capacity $\left(\mathrm{C}_{p}\right)$ of long chain diesters were analyzed with Netzsch DSC214 Polyma model differential scanning calorimetry (DSC) instrument.
The instrument was calibrated with bismuth, indium, and zinc, tin, and cesium chloride internal standards for the measurements as with sapphire internal standard for $\mathrm{C}_{p}$ measurements. The DSC measurements were performed at a heating-cooling rate of $1{ }^{\circ} \mathrm{C} \mathrm{min}-1$ in temperature range of $0{ }^{\circ} \mathrm{C}$ to $80{ }^{\circ} \mathrm{C}$ under inert $\mathrm{N}_{2}$ atmosphere at a flow rate of $60 \mathrm{~mL} / \mathrm{min} . \mathrm{C}_{p}$ values of fatty alcohols, DTA and DOA were determined between $-10{ }^{\circ} \mathrm{C}$ and $100{ }^{\circ} \mathrm{C}$ and $5{ }^{\circ} \mathrm{C} \mathrm{min}{ }^{-1}$ heatingcooling rate was applied. Thermal stability, weight loss temperatures and decomposition behavior of the novel PCMs were detected with Seteram TG-DTA/DSC model TGA instrument. The measurements were performed at a scanning rate of $10^{\circ} \mathrm{C} / \mathrm{min}$ in a static air atmosphere and instrument was calibrated using calcium oxalate standard from 35 to $500{ }^{\circ} \mathrm{C}$.

\subsubsection{Morphology analyses}

Fatty alcohols and long-chain diesters were monitored for crystalline morphology investigation with Leica DM EP model (Germany, 2010) polarize optical microscope (POM).

\subsubsection{Thermal cycling and durability investigation}

For determination of thermal reliability of long-chain diesters, thermal cycling test was carried out 1000 times using a BIOER TC-25/H model thermal cycler. After accelerated thermal cycling, FT-IR and DSC measurement of PCMs were repeated.

\section{Results and Discussion}

\subsection{The chemical characterization of the long-chain diesters}

FT-IR and ${ }^{1}$ HNMR spectroscopy methods were used to verify to chemical structures of synthesized longchain diesters. FT-IR spectra of 1-tetradecanol, 1octadecanol, adipic acid, DTA and DOA are exhibited in Figure 2, as Table 2 specifies wavenumber and characteristic band of precursors and long-chain diesters. According to Figure 2, the O-H out-plane bending peak of 1-tetradecanol, 1-octadecanol and adipic acid were seen at 1057, 1061 and $921 \mathrm{~cm}^{-1}$, respectively as $\mathrm{O}-\mathrm{H}$ vibration bands of precursors at $2978-3480 \mathrm{~cm}^{-1}$ were also cleared away in diesters. The $\mathrm{C}-\mathrm{O}-\mathrm{C}$ peak which is not seen in the precursor materials were recorded at 1159 and $1162 \mathrm{~cm}^{-1}$ in the synthesized DTA and DOA, respectively. The disappearance of hydroxyl peaks and formation of ether peak showed that hydroxyl groups of fatty alcohols and adipic acid converted to ester bond. 
Besides $\mathrm{C}=\mathrm{O}$ stretching peak of adipic acid at $1680 \mathrm{~cm}^{-}$ ${ }^{1}$ were observed at $1728 \mathrm{~cm}^{-1}$ after synthesis of longchain diesters.

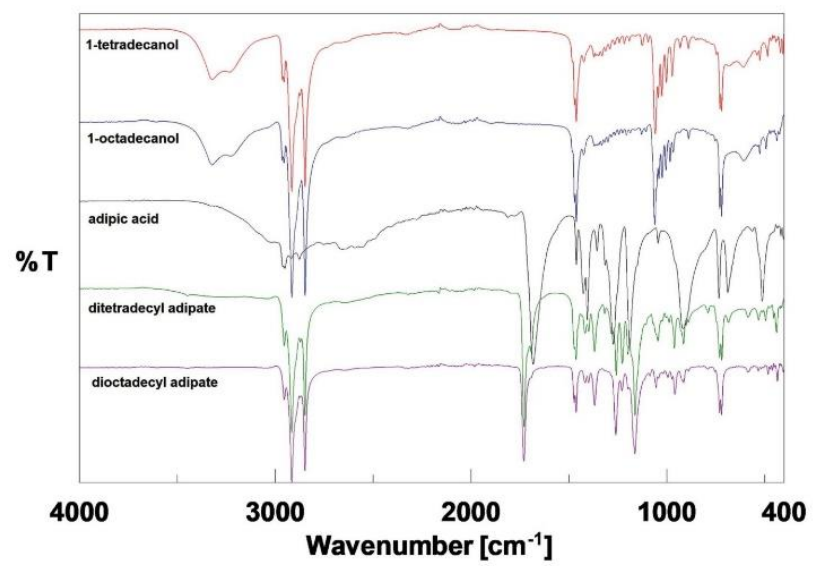

Figure 2. FT-IR spectra of fatty alcohols, adipic acid and long-chain diesters

Table 2. FT-IR data of fatty alcohols, adipic acid and longchain diesters

\begin{tabular}{|c|c|c|}
\hline Materials & $\begin{array}{l}\text { Wavenumber } \\
{\left[\mathrm{cm}^{-1}\right]}\end{array}$ & Characteristic band \\
\hline 1-tetradecanol & $\begin{array}{l}1057 \\
1455 \\
2845 \text { and } 2912 \\
3100-3480\end{array}$ & $\begin{array}{l}\text { O-H out-plane bending } \\
\text { peak } \\
\mathrm{C}-\mathrm{O} \text { in-plane bending } \\
\text { peak } \\
\mathrm{C}-\mathrm{H} \text { vibration and } \\
\text { bending peaks } \\
\mathrm{O}-\mathrm{H} \text { vibration bands }\end{array}$ \\
\hline 1-octadecanol & $\begin{array}{l}1061 \\
1459 \\
2845 \text { and } 2912 \\
3100-3480\end{array}$ & $\begin{array}{l}\text { O-H out-plane bending } \\
\text { peak } \\
\mathrm{C}-\mathrm{O} \text { in-plane bending } \\
\text { peak } \\
\mathrm{C}-\mathrm{H} \text { vibration and } \\
\text { bending peaks } \\
\mathrm{O}-\mathrm{H} \text { vibration bands }\end{array}$ \\
\hline adipic acid & $\begin{array}{l}921 \\
1271 \\
1404 \text { and } 1425 \\
1680 \\
2876 \text { and } 2957 \\
2978-3284\end{array}$ & $\begin{array}{l}\text { O-H out-plane bending } \\
\text { peak } \\
\mathrm{C}-\mathrm{O} \text { stretching peak } \\
\mathrm{C}-\mathrm{O} \text { in-plane bending } \\
\text { peaks } \\
\mathrm{C}=\mathrm{O} \text { stretching peak } \\
\mathrm{C}-\mathrm{H} \text { vibration and } \\
\text { bending peaks } \\
\mathrm{O}-\mathrm{H} \text { vibration bands }\end{array}$ \\
\hline DTA & $\begin{array}{l}1159 \\
1258 \\
1452 \text { and } 1472 \\
1728 \\
2845 \text { and } 2913\end{array}$ & $\begin{array}{l}\mathrm{C}-\mathrm{O}-\mathrm{C} \text { bending peak } \\
\mathrm{C}-\mathrm{O} \text { stretching peak } \\
\mathrm{C}-\mathrm{O} \text { in-plane bending } \\
\text { peaks } \\
\mathrm{C}=\mathrm{O} \text { stretching peak } \\
\mathrm{C}-\mathrm{H} \text { vibration and } \\
\text { bending peaks }\end{array}$ \\
\hline$\overline{\mathrm{DOA}}$ & $\begin{array}{l}1162 \\
1258 \\
1459 \text { and } 1469 \\
1728 \\
2844 \text { and } 2914\end{array}$ & $\begin{array}{l}\mathrm{C}-\mathrm{O}-\mathrm{C} \text { bending peak } \\
\mathrm{C}-\mathrm{O} \text { stretching peak } \\
\mathrm{C}-\mathrm{O} \text { in-plane bending } \\
\text { peaks } \\
\mathrm{C}=\mathrm{O} \text { stretching peak } \\
\mathrm{C}-\mathrm{H} \text { vibration and } \\
\text { bending peaks }\end{array}$ \\
\hline
\end{tabular}

The ${ }^{1}$ HNMR spectra of DTA and DOA were shown in Figure 3. The introduced peaks were appointed to the protons of $\mathrm{CDCl}_{3}(\delta=7.28 \mathrm{ppm})$ labeled with a $\left(-\mathrm{CH}_{3}\right)$ at about $\delta=0.9(\mathrm{t}, \mathrm{J}=6.8 \mathrm{~Hz}, 6 \mathrm{H})$, labeled with $\mathrm{b}(-$ $\left(\mathrm{CH}_{2}\right)_{11^{-}}$and $\left.-\left(\mathrm{CH}_{2}\right)_{15}\right)$ at about $\delta=0.98-1.38(\mathrm{~m}, 44 \mathrm{H}$ or $60 \mathrm{H}$ ), labeled with $\mathrm{c}$ at about $\delta=2.37$ (ddd, $\mathrm{J}=11.0$, $7.0,2.2 \mathrm{~Hz}, 4 \mathrm{H})$, labeled with $\mathrm{d}$ at about $\delta=4.07(\mathrm{t}$, $\mathrm{J}=6.8 \mathrm{~Hz}, 4 \mathrm{H})$ and labeled with $\mathrm{e}$ and $\mathrm{f}$ ($\left.\mathrm{COO}\left(\mathrm{CH}_{2}\right)_{4} \mathrm{COO}-\right)$ at about $\delta=1.75-1.48(\mathrm{~m}, 8 \mathrm{H})$ for dicarboxylic acid esters. The chemical shifts and number of protons of DTA and DOO proved at successful synthesis.

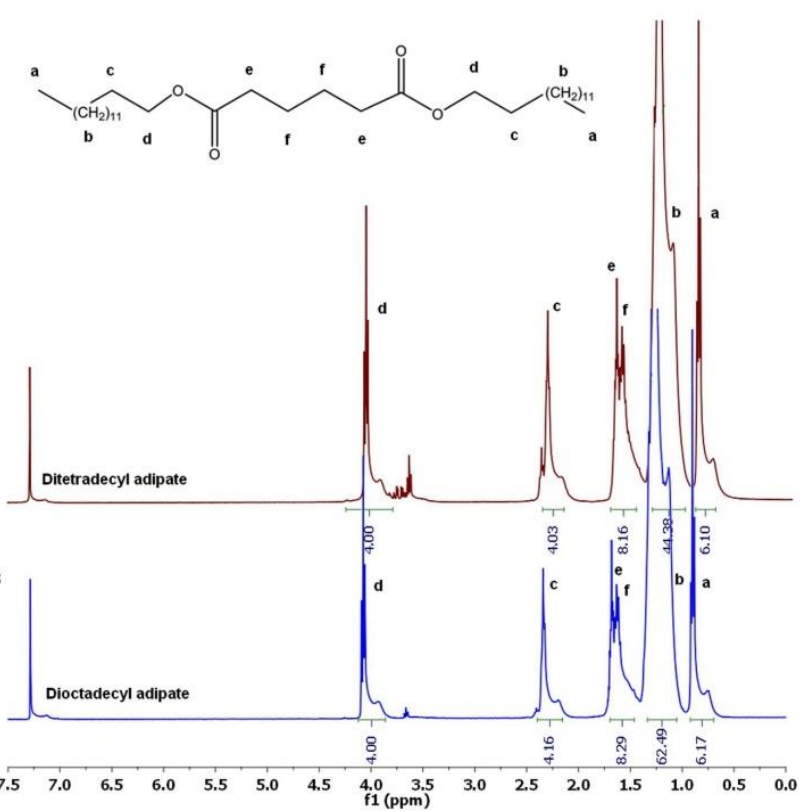

Figure 3. ${ }^{1} \mathrm{H}$ NMR spectra of DTA and DOA

\subsection{Thermal characterization of the long-chain diesters}

It is necessary to determine TES properties like phase change enthalpy, melting-solidification temperatures, and overcooling for identification of PCMs. DSC is the most preferred method for thermal characterization. DSC curves of fatty alcohols and synthesized longchain diesters were presented in Figure 4 and in Table 3 as DSC data. Solid-solid and melting phase transformation were overlapped in 1-tetradecanol and 1-octadecanol DSC curves and melting and solidification temperatures were found as 36 and $35^{\circ} \mathrm{C}$ respectively for 1-tetradecanol, as melting and solidification temperatures were found 50 and $56{ }^{\circ} \mathrm{C}$ respectively for 1-octadecanol. Melting and solidification enthalpies of 1-tetradecanol were 236.2 and $-234.0 \mathrm{Jg}^{-1}$ respectively, as melting and solidification enthalpies of 1-octadecanol were measured as 252.3 and $-254.6 \mathrm{Jg}^{-1}$ respectively. The synthesized long-chain diesters had solid-solid and 
melting phase change behavior at different temperatures unlike fatty alcohols. Solid-solid phase change temperatures of DTA were found as 28 and 33 ${ }^{\circ} \mathrm{C}$ and solid-solid phase change enthalpies were found as 19.8 and $-19.7 \mathrm{Jg}^{-1}$ for heating and cooling periods. For DOA, solid-solid transitions occur with a very low enthalpy for heating and cooling periods. The melting and solidification temperatures of long-chain diesters were 44 and $43{ }^{\circ} \mathrm{C}$ respectively for DTA and 60 and 60 ${ }^{\circ} \mathrm{C}$ for DOA. At $1{ }^{\circ} \mathrm{C} \mathrm{min}^{-1}$ heating and cooling rates, DOA has never showed supercooling behavior, while DTA has only $1{ }^{\circ} \mathrm{C}$ supercooling. Phase change enthalpy values of the diesters were found as 142.4 and $-147.8 \mathrm{Jg}^{-1}$ for DTA and 186.2 and $-175.5 \mathrm{Jg}^{-1}$ for DOA. The phase change temperatures of DTS and DOS were slightly higher than those of precursor fatty alcohols unlike phase change enthalpies which were lower than fatty alcohols. Because the middle segment of the diester molecules distorts crystallinity more than hydrogen bonding segments of the alcohols. In spite of long-chain diesters have lower enthalpy than fatty alcohols; DTA and DOA have enough enthalpy to be used in solar energy storage systems.

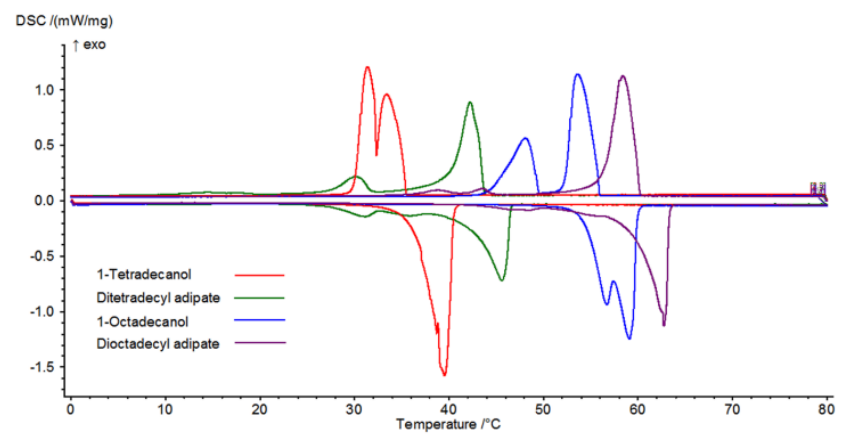

Figure 4. DSC curves of fatty alcohols and long-chain diesters

Table 3. TES properties of fatty alcohols and long-chain diesters

\begin{tabular}{|c|c|c|c|c|}
\hline Materials & $\begin{array}{l}\text { Melting } \\
\text { temperature }\left({ }^{\circ} \mathrm{C}\right) \\
\end{array}$ & $\begin{array}{l}\text { Melting } \\
\text { enthalpy }\left(\mathrm{Jg}^{-1}\right)\end{array}$ & \begin{tabular}{|l|l|} 
Solidification \\
temperature $\left({ }^{\circ} \mathrm{C}\right)$ \\
\end{tabular} & $\begin{array}{ll}\begin{array}{l}\text { Solidification enthalpy } \\
\left(\mathrm{Jg}^{-1}\right)\end{array} \\
\end{array}$ \\
\hline 1-tetradecanol & 36 & 236.2 & 35 & -234.0 \\
\hline 1-octadecanol & 50 & 252.3 & 56 & -254.6 \\
\hline DTA & 44 & 142.4 & 43 & -147.8 \\
\hline $\mathrm{DOA}$ & 60 & 186.2 & 60 & -175.5 \\
\hline
\end{tabular}

The total enthalpy is an important parameter to determine the total thermal energy stored by the PCM in the operating temperature range. It also provides information on the over cooling behavior of PCM $[47,48]$. Total thermal energy values of the novel PCMs have been determined by the method of Mehling et al. [49]. Total enthalpy calculation showed latent heat storage capacity along with sensible heat capacity of fatty alcohols and long-chain diesters between 0 and $80{ }^{\circ} \mathrm{C}$ in Figure 5. According to calculation, 1tetradecanol and 1-octadecanol were stored thermal energy up to 394.6 and $431.2 \mathrm{Jg}^{-1}$ respectively, as new novel PCMs were stored thermal energy up to $350.4 \mathrm{Jg}$ ${ }^{1}$ for DTA, up to $357.5 \mathrm{Jg}^{-1}$ for DOA.

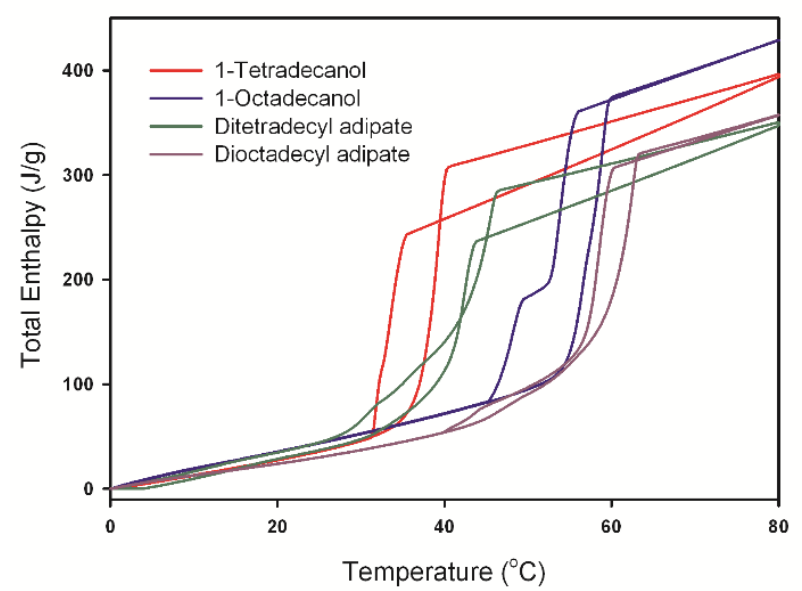

Figure 5. Total enthalpy values of fatty alcohols and longchain diesters

In many studies performed to store thermal energy, only phase change temperature and energy storage density of PCMs were investigated whereas the $\mathrm{C}_{p}$ value is directly related to the ability of PCM to store sensible energy. Therefore, $\mathrm{C}_{p}$ values of synthesized long-chain diesters and fatty alcohols were calculated using DSC instrument calibrated with sapphire internal standard. Figure 6 demonstrated $\mathrm{C}_{p}$ curves of fatty alcohols, DTA and DOA as the data were given in Table 4 for $-10-100{ }^{\circ} \mathrm{C}$. 


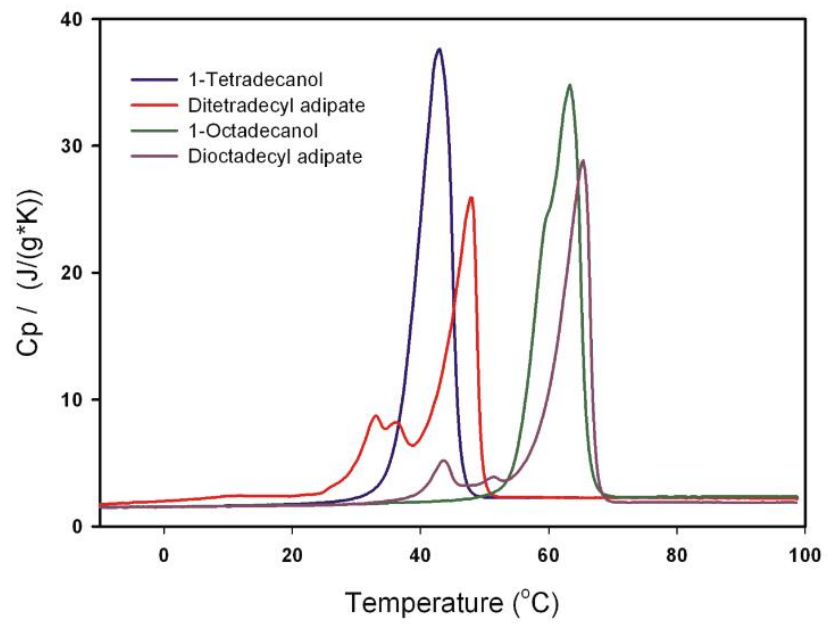

Figure 6. $\mathrm{Cp}$ versus temperature curves of fatty alcohols and long-chain diesters

Table 4. Cp values of fatty alcohols and long-chain diesters

\begin{tabular}{|c|c|c|c|c|c|}
\hline \multirow{8}{*}{ 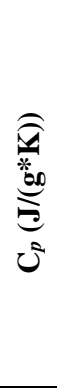 } & Temperature $\left({ }^{\circ} \mathrm{C}\right)$ & 1-tetradecanol & 1-octadecanol & DTA & DOA \\
\hline & $-10^{\circ} \mathrm{C}$ & 1.5 & 1.5 & 1.7 & 1.5 \\
\hline & $0^{\circ} \mathrm{C}$ & 1.6 & 1.6 & 2.0 & 1.5 \\
\hline & $20^{\circ} \mathrm{C}$ & 1.8 & 1.7 & 2.4 & 1.7 \\
\hline & before solid-solid phase change & & & $\begin{array}{l}3.8 \\
\left(28^{\circ} \mathrm{C}\right)\end{array}$ & $\begin{array}{l}2.8 \\
\left(40^{\circ} \mathrm{C}\right)\end{array}$ \\
\hline & before solid-liquid phase change & $\begin{array}{l}6.5 \\
\left(36^{\circ} \mathrm{C}\right)\end{array}$ & $\begin{array}{l}2.5 \\
\left(50^{\circ} \mathrm{C}\right)\end{array}$ & $\begin{array}{l}13.8 \\
\left(44^{\circ} \mathrm{C}\right)\end{array}$ & $\begin{array}{l}10.9 \\
\left(60^{\circ} \mathrm{C}\right)\end{array}$ \\
\hline & $80^{\circ} \mathrm{C}$ & 2.3 & 2.4 & 2.3 & 1.9 \\
\hline & $100^{\circ} \mathrm{C}$ & 2.3 & 2.3 & 2.2 & 1.9 \\
\hline
\end{tabular}

Thermal durability is very important parameter of PCMs because TGA measurements show working temperature range. The starting temperature of decomposition is especially important since it shows the maximum temperature at which the PCMs can be used. The decomposition temperature graphs of dicarboxylic acid esters were given in Figure 7 as TGA data were tabulated in Table 5. Single-step degradation behavior was observed in both DTA and DOO. The onset starting and ending temperatures of DTA were decomposition temperature range of DTA was monitored between 248.3 and $425.4{ }^{\circ} \mathrm{C}$ respectively with $88.5 \%$ mass loss as onset temperatures of DOA was monitored as 343.5 and $434.8^{\circ} \mathrm{C}$ respectively with $90.3 \%$ mass loss. As clearly seen from thermal analyses, as the number of carbon atoms increase in the chain, the thermal resistance of diesters increases.

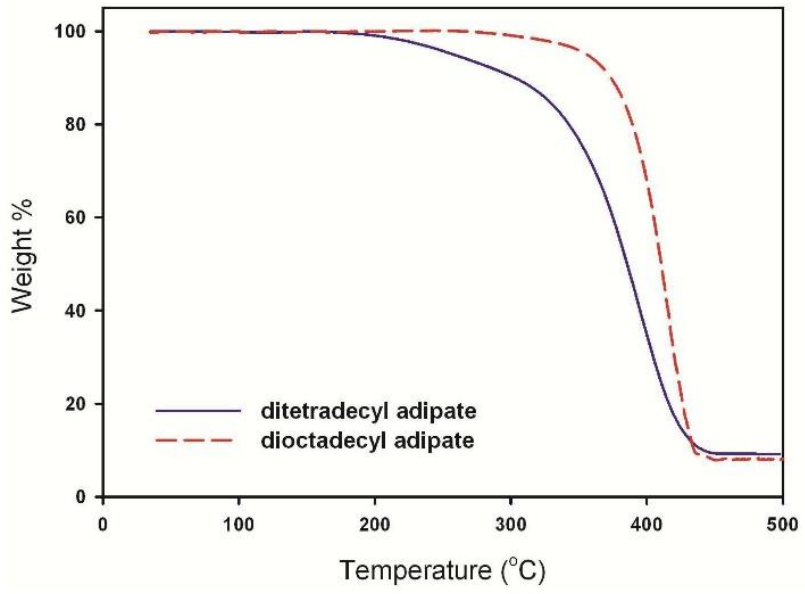

Figure 7. TGA curves of long-chain diesters

Table 5. Thermal durability limits of long-chain diesters

\begin{tabular}{llll}
\hline Materials & $\begin{array}{l}\text { Decomposition } \\
\text { onset } \\
\text { temperatures } \\
\left({ }^{\circ} \mathbf{C}\right)\end{array}$ & $\begin{array}{l}\text { Weight } \\
\text { loss [\%] }\end{array}$ & $\begin{array}{l}\text { DTGmax } \\
\text { temperature } \\
\left({ }^{\circ} \mathbf{C}\right)\end{array}$ \\
\hline DTA & $248.3-425.4$ & 88.5 & 388.7 \\
\hline DOA & $343.5-434.8$ & 90.3 & 407.6 \\
\hline
\end{tabular}




\subsection{Morphological investigation of the long-chain diesters}

Polarized optical microscope images of fatty alcohols and long-chain diesters' polarized optical microscope images were given in Figure 8 below phase change temperatures. It can be watched that synthesized PCM and precursor fatty alcohols had slightly different phase views.

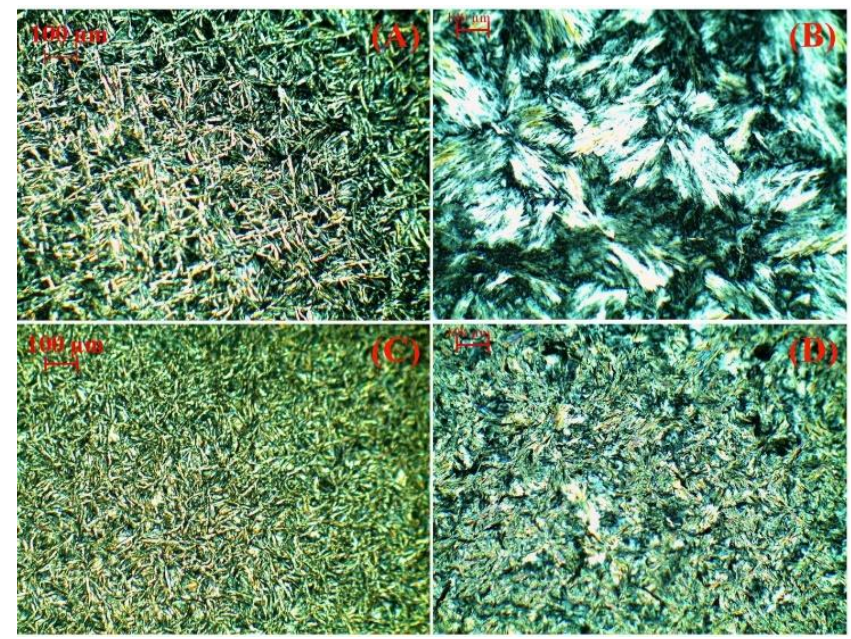

Figure 8. POM images of 1-tetradecanol (A), DTA (B), 1octadecanol (C), and DOA (D).

\subsection{Thermal reliability of the long-chain diesters}

Materials to be used as PCMs should be thermally and chemically stable at the end of a large number of heating-cooling cycles, therefore lifetime of PCMs should be determined. In this study, thermal reliability and chemical stability of long-chain diesters was determined using DNA thermal cycler after 1000 times melting and freezing cycles. Thermal stability such as phase change enthalpies and temperatures of DTA and
DOA were redetermined with DSC measurements as DSC curves of long-chain diestres were given in Figure 9 and obtained all data were given in Table 6.

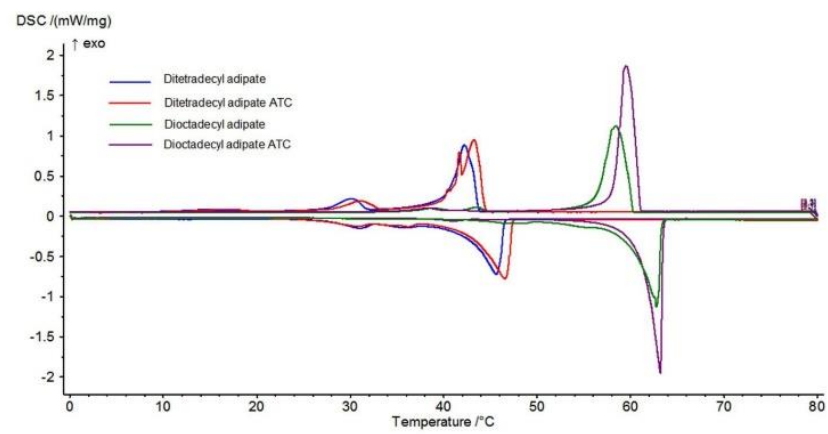

Figure 9. DSC thermograms of DTA and DOA before and after 1000 accelerated thermal cycling.

DSC results showed that DTA and DOA had solidsolid phase change behavior. Solid-solid phase transitions in DOA still had very low enthalpy for heating and cooling periods. For DTA, solid-solid phase change temperatures were found as 30 and $32{ }^{\circ} \mathrm{C}$ as solid-solid phase change enthalpies were found as slightly decreased after thermal cycling. The soli-solid phase transition enthalpies were found as 16.4 and $18.6 \mathrm{Jg}^{-1}$ for heating and cooling periods after accelerated thermal cycling respectively. Only freezing temperature of DTA changed $1{ }^{\circ} \mathrm{C}$ after thermal cycling. For DOA, both melting and solidifications temperature increased $1{ }^{\circ} \mathrm{C}$ after thermal cycling. No super cooling behavior was observed in both diesters after accelerated thermal cyclings. In addition to that, phase change enthalpies of the new PCMs increased slightly as compared to non-thermal conversions.

Table 6. Thermal reliability characteristics of DTA and DOA before and after thermal cyclings

\begin{tabular}{|c|c|c|c|c|}
\hline Materials & $\begin{array}{l}\text { Melting } \\
\text { temperature }\left({ }^{\circ} \mathbf{C}\right)\end{array}$ & $\begin{array}{l}\text { Melting enthalpy } \\
\left(\mathbf{J g}^{-1}\right)\end{array}$ & $\begin{array}{l}\text { Solidification } \\
\text { temperature }\left({ }^{\circ} \mathrm{C}\right)\end{array}$ & $\begin{array}{l}\text { Solidification } \\
\text { enthalpy }\left(\mathrm{Jg}^{-1}\right)\end{array}$ \\
\hline DTA & 44 & 142.4 & 43 & -147.8 \\
\hline DTA ATC & 44 & 145.5 & 44 & -144.4 \\
\hline DOA & 60 & 186.2 & 60 & -175.5 \\
\hline DOA ATC & 61 & 217.1 & 61 & -209.9 \\
\hline
\end{tabular}

Besides, chemical stability was investigated using FTIR analysis. Figure 10 showed FT-IR spectra of longchain diesters comparatively before and after thermal cycling. Peak shape and positions of PCMs persisted after 1000 accelerated thermal cyclings. DSC and FTIR results proved that there was no any degradation, decomposition, and sublimation in synthesized PCMs after 1000 thermal cycling and PCMs are very stable at possible ambient temperatures. 


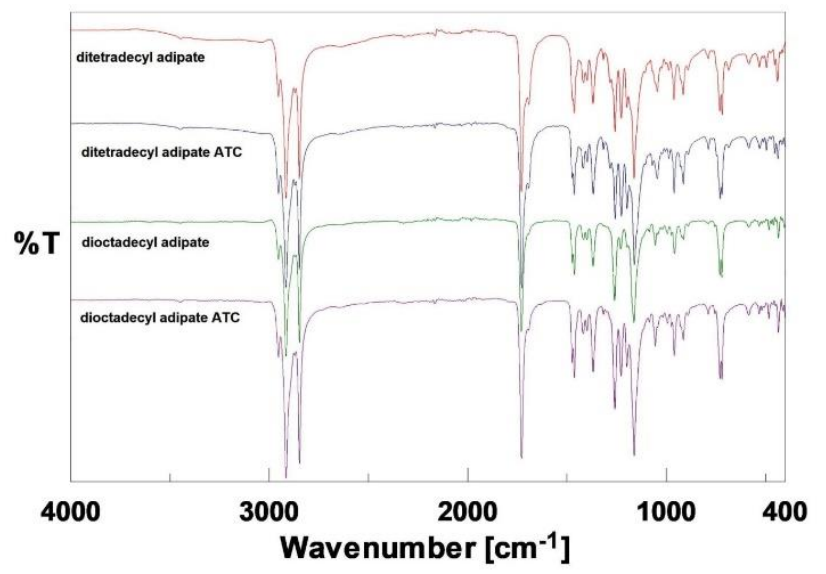

Figure 10. FTIR spectra of long-chain diesters before and after 1000 accelerated thermal cycling

\section{Conclusions}

In this work, long-chain diesters starting from adipic acid and two different fatty alcohols were synthesized with high purity as efficient as novel PCMs and characterized structurally by using FTIR and ${ }^{1}$ HNMR spectroscopy techniques.

DSC and TG analyses indicated that synthesized DTA and DOA have high enthalpy, suitable phase change temperatures and they are stable up to high temperature for thermal energy storage applications. Phase change enthalpies of long-chain diesters were slightly lower than fatty alcohols because of diadipate groups in the chain which disrupted the crystallinity of side groups. Latent heat capacity of DTA and DOA were measured as 142.4 and 186.2 for heating periods, respectively. Besides, melting enthalpy of DTA and DOA changed $2.18 \%$ and $16.60 \%$ respectively after 1000 times thermal cyclings which was attributed to thermal effect on phase separation of crystallizable groups. In addition, total enthalpy and $\mathrm{C}_{p}$ values were associated with thermal storage capacity and they were calculated for applicable temperature range.

In literature, lots of organic PCMs have been studied as TES material (Table 1). Among the PCM, paraffins, fatty alcohols and fatty acids are have high enthalpy for TES, however they are not stable. For this reason, many studies have been working on better stabilized functional materials. In this case, functionalization may result to drop in enthalpy. Esters are very much interested due to their stability among the synthetic PCMs. In the literature, there are limited studies on the use of esters as PCM. Table 7 showed that some ester compounds and their TES properties in the literature.

Table 7. Some ester compounds and their TES properties in the literature

\begin{tabular}{llllll}
\hline Compound & $\begin{array}{l}\text { Melting } \\
\text { Temperature } \\
\left({ }^{\circ} \mathbf{C}\right)\end{array}$ & $\begin{array}{l}\text { Freezing } \\
\text { Temperature } \\
\left({ }^{\circ} \mathbf{C}\right)\end{array}$ & $\begin{array}{l}\text { Melting } \\
\text { Enthalpy } \\
\left(\mathbf{J g}^{-1}\right)\end{array}$ & $\begin{array}{l}\text { Freezing } \\
\text { Enthalpy } \\
\left(\mathbf{J g}^{-1}\right)\end{array}$ \\
\hline Esters & butyl stearate [40] & 23.7 & 24.5 & 121.0 & -128.4 \\
& isopropyl stearate [40] & 22.1 & 22.0 & 113.1 & -111.3 \\
& glycerol tristearate [40] & 63.5 & 64.6 & 149.4 & -151.7 \\
& ditetradecyl oxalate [43] & 47 & 44 & 210.6 & -208.3 \\
& dioctadecyl oxalate [43] & 65 & 63 & 244.9 & -241.7 \\
& ditetradecyl succinate [44] & 47 & 46 & 202.4 & -197.5 \\
& dioctadecyl succinate [44] & 64 & 63 & 194.9 & -191.7 \\
& methyl stearate [50] & 37.8 & 37.6 & 240 & -237 \\
& methyl palmitate [50] & 29.0 & 28.7 & 215 & -214 \\
& tetradecyl dodecanoate [51] & 38.1 & 36.2 & 207.9 & -207.8 \\
& tetradecyl tetradecanoate [51] & 41.6 & 40.0 & 210.4 & -211.0 \\
tetradecyl hexadecanoate [51] & 48.0 & 47.5 & 213.9 & -214.1 \\
tetradecyl octadecanoate [51] & 49.6 & 48.3 & 221.8 & -222.1 \\
tetradecyl eicosonoate [51] & 52.8 & 51.8 & 201.3 & 200.3 \\
\hline
\end{tabular}

Within this framework, long-chain diesters easily were synthesized without any catalyst. All reactions cared out solvent free condition and under vacuum. In comparison to traditional Fisher esterification, used synthetic method overcome water removal problem which occur as a byproduct at the end of the reaction. Our results show that new PCMs were not corrosive, malodorous and stable compared with fatty alcohol and fatty acids. Thermal cycling tests results suggested that the new PCM show better thermal stability in comparison to fatty acid and fatty alcohols. Thanks to superiority of synthesized long-chain diesters can be used as new alternatives for energy storage applications at large scale such as solar energy storage, building heating or cooling and indoor temperature controlling.

\section{Acknowledgment}


The author would like to thank Tokat Gaziosmanpaşa University Polymer Research Laboratory for the materials and facilities.

\section{Conflicts of interest}

The authors state that did not have conflict of interests.

\section{References}

[1] Mao Q., Chen H., Zhao Y., and Wu H. A novel heat transfer model of a phase change material using in solar power plant. Appl. Therm. Eng, 129 (2018) 557-563.

[2] Tao Y. B. and He Y. L. A review of phase change material and performance enhancement method for latent heat storage system. Renew. Sustain. Energy Rev., 93 (2018) 245-259.

[3] Rezaie A. B. and Montazer M. One-step fabrication of fatty acids/nano copper/polyester shape-stable composite phase change material for thermal energy management and storage. Appl. Energy., 228 (2018) 1911-1920.

[4] Zhang P., Meng Z. N., Zhu H., Wang Y. L., and Peng S. P. Melting heat transfer characteristics of a composite phase change material fabricated by paraffin and metal foam. Appl. Energy., 185 (2017) 1971-1983.

[5] Lin Y., Jia Y., Alva G., and Fang G. Review on thermal conductivity enhancement, thermal properties and applications of phase change materials in thermal energy storage, Renew. Sustain. Energy Rev., 82 (2018) 2730-2742.

[6] Behzadi S. and Farid M. M. Long term thermal stability of organic PCMs. Appl. Energy, 122 (2014) 11-16.

[7] Zalba B., Marín J. M., Cabeza L. F., and Mehling H. Review on thermal energy storage with phase change: materials, heat transfer analysis and applications. Appl. Therm. Eng., 23 (2003) 251-283.

[8] Sharma A., Tyagi V. V., Chen C. R., and Buddhi D. Review on thermal energy storage with phase change materials and applications. Renew. Sustain. Energy Rev., 13 (2009) 318-345.

[9] Parameshwaran R., Kalaiselvam S., Harikrishnan S., and Elayaperumal A. Sustainable thermal energy storage technologies for buildings: A review. Renew. Sustain. Energy Rev., 16 (2012) 2394-2433.

[10] Sar1 A., Bicer A., Karaipekli A., and AlSulaiman F.A. Preparation, characterization and thermal regulation performance of cement based-composite phase change material. Sol. Energy Mater. Sol. Cells., 174 (2018) 523-529.

[11] Yuan Y., Cao X., Xiang B., and Du Y. Effect of installation angle of fins on melting characteristics of annular unit for latent heat thermal energy storage. Sol. Energy., 136 (2016) 365-378.

[12] Zeinelabdein R., Omer S., and Gan G. Critical review of latent heat storage systems for free cooling in buildings. Renew. Sustain. Energy Rev., 82 (2018) 2843-2868.

[13] Liu M., Steven Tay N. H., Bell S., Belusko M., Jacob R., Will G., Saman W., and Bruno F. Review on concentrating solar power plants and new developments in high temperature thermal energy storage Technologies. Renew. Sustain. Energy Rev., 53 (2016) 1411-1432.

[14] Pardo P., Deydier A., Anxionnaz-Minvielle Z., Rougé S., Cabassud M., and Cognet P. A review on high temperature thermochemical heat energy storage. Renew. Sustain. Energy Rev., 32 (2014) 591-610.

[15] Fernandez A. I., Martínez M., Segarra M., Martorell I., Cabeza L. F. Selection of materials with potential in sensible thermal energy storage. Sol. Energy Mater. Sol. Cells., 94 (2010) 1723-1729.

[16] Kenisarin M. and Mahkamov K. Salt hydrates as latent heat storage materials:Thermophysical properties and costs. Sol. Energy Mater. Sol. Cells., 145 (2016) 255-286.

[17] Wang Q., Wang J., Chen Y., and Zhao C.Y. Experimental investigation of barium hydroxide octahydrate as latent heat storage materials. Sol. Energy., 177 (2019) 99-107.

[18] Baetens R., Jelle B.P., and Gustavsen A. Phase change materials for building applications: A state-of-the-art review. Energy Build., 42 (2010) 1361-1368.

[19] Zhou D., Zhao C.Y., and Tian Y. Review on thermal energy storage with phase change materials (PCMs) in building applications. Appl. Energy., 92 (2012) 593-605.

[20] Kahraman Döğüşcü D., Kızıl Ç., Biçer A., Sarı A., and Alkan C. Microencapsulated n-alkane eutectics in polystyrene for solar thermal applications. Sol. Energy., 160 (2018) 32-42.

[21] Alkan C., Sar1 A., and Karaipekli A. Preparation, thermal properties and thermal reliability of microencapsulated n-eicosane as novel phase change material for thermal energy storage. Energy Convers. Manag., 52 (2011) 687-692.

[22] Alkan C. and Sari A. Fatty acid/poly(methyl methacrylate) (PMMA) blends as form-stable 
phase change materials for latent heat thermal energy storage. Sol. Energy., 82 (2008) 118124.

[23] Zuo J., Li W., and Weng L. Thermal performance of caprylic acid/1-dodecanol eutectic mixture as phase change material (PCM). Energy Build., 43 (2011) 207-210.

[24] Cheng F., Wen R., Zhang X., Huang Z. Huang Y., Fang M., Liu Y., Wu X., and Min X., Synthesis and characterization of beeswaxtetradecanol-carbon fiber/expanded perlite form-stable composite phase change material for solar energy storage. Compos. Part A Appl. Sci. Manuf., 107 (2018) 180-188.

[25] Wang Y., Liu Z., Zhang T., and Zhang Z. Preparation and Characterization of Graphene Oxide-Grafted Hexadecanol Composite PhaseChange Material for Thermal Energy Storage. Energy Technol., 5 (2017) 2005-2014.

[26] Lv P., Ding M., Liu C., and Rao Z. Experimental investigation on thermal properties and thermal performance enhancement of octadecanol/expanded perlite form stable phase change materials for efficient thermal energy storage. Renew. Energy., 131 (2019) 911-922.

[27] Ma G., Sun J., Zhang Y., Jing Y., and Jia Y. Preparation and thermal properties of stearic acid-benzamide eutectic mixture/expanded graphite composites as phase change materials for thermal energy storage. Powder Technol., 342 (2019) 131-140.

[28] Hou P., Mao J., Chen F., Li Y., Dong X., Hou P., Mao J., Chen F., Li Y., and Dong X. Preparation and Thermal Performance Enhancement of Low Temperature Eutectic Composite Phase Change Materials Based on Na2SO4·10H2O. Materials, 11 (2018) 2230.

[29] Sarı A., Alkan C., Döğüşcü D.K., and Kızıl Ç. Micro/nano encapsulated n-tetracosane and noctadecane eutectic mixture with polystyrene shell for low-temperature latent heat thermal energy storage applications. Sol. Energy., 115 (2015) 195-203.

[30] Döğüşcü D.K., Altıntaş A., Sarı A., and Alkan C. Polystyrene microcapsules with palmiticcapric acid eutectic mixture as building thermal energy storage materials. Energy Build., 150 (2017) 376-382.

[31] Stamatiou A., Obermeyer M., Fischer L.J., Schuetz P., and Worlitschek J. Investigation of unbranched, saturated, carboxylic esters as phase change materials. Renew. Energy., 108 (2017) 401-409.

[32] Pielichowski K. and Flejtuch K. Differential scanning calorimetry studies on poly(ethylene glycol) with different molecular weights for thermal energy storage materials. Polym. Adv. Technol., 13 (2002) 690-696.

[33] Baykut F., Aydin A. The synthesis and physical properties of the homologous series of fatty acids' esters. Reveu La Fac. Des Sci. L'Universite D'Istanbul Ser. C., (1969) 119_ 148.

[34] Parameshwaran R., Jayavel R., and Kalaiselvam S. Study on thermal properties of organic ester phase-change material embedded with silver nanoparticles. J. Therm. Anal. Calorim., 114 (2013) 845-858.

[35] Wi S., Seo J., Jeong S. G., Chang S. J., Kang Y., and Kim S. Thermal properties of shapestabilized phase change materials using fatty acid ester and exfoliated graphite nanoplatelets for saving energy in buildings. Sol. Energy Mater. Sol. Cells., 143 (2015) 168-173.

[36] Aydin A.A. Fatty acid ester-based commercial products as potential new phase change materials (PCMs) for thermal energy storage. Sol. Energy Mater. Sol. Cells., 108 (2013) 98104.

[37] Feldman D., Banu D., Hawes D., and Ghanbari E. Obtaining an energy storing building material by direct incorporation of an organic phase change material in gypsum wallboard. Sol. Energy Mater. Sol. Cells., 22 (1991) 231-242.

[38] Feldman D., Banu D., and Hawes D. Low chain esters of stearic acid as phase change materials for thermal energy storage in buildings. Sol. Energy Mater. Sol. Cells., 36 (1995) 311-322.

[39] Sarı A., Biçer A., Karaipekli A., Alkan C., and Karadag A. Synthesis, thermal energy storage properties and thermal reliability of some fatty acid esters with glycerol as novel solid-liquid phase change materials. Sol. Energy Mater. Sol. Cells., 94 (2010) 1711-1715.

[40] Sarı A., Biçer A., and Karaipekli A. Synthesis, characterization, thermal properties of a series of stearic acid esters as novel solid-liquid phase change materials. Mater. Lett., 63 (2009) 12131216.

[41] Sarı A. and Biçer A. Thermal energy storage properties and thermal reliability of some fatty acid esters/building material composites as novel form-stable PCMs. Sol. Energy Mater. Sol. Cells., 101 (2012) 114-122.

[42] Sarı A. and Karaipekli A. Fatty acid esters-based composite phase change materials for thermal energy storage in buildings. Appl. Therm. Eng., 37 (2012) 208-216.

[43] Kahraman Döğüşcü D. Tetradecyl oxalate and octadecyl oxalate as novel phase change 
materials for thermal energy storage. Sol. Energy., 185 (2019) 341-349.

[44] Kahraman Döğüşcü D. Synthesis and characterization of ditetradecyl succinate and dioctadecyl succinate as novel phase change materials for thermal energy storage. Sol. Energy Mater. Sol. Cells., 200 (2019) 110006.

[45] Aydın A.A., and Okutan H. Polyurethane rigid foam composites incorporated with fatty acid ester-based phase change material. Energy Convers. Manag., 68 (2013) 74-81.

[46] Aydin A.A. In situ preparation and characterization of encapsulated high-chain fatty acid ester-based phase change material (PCM) in poly(urethane-urea) by using amino alcohol. Chem. Eng. J., 231 (2013) 477-483.

[47] Alkan C., Gunther E., Hiebler S., Ensari O.F., and Kahraman D. Polyurethanes as solid-solid phase change materials for thermal energy storage. Sol. Energy., 86(6) (2012) 1761-1769.

[48] Alkan C., Günther E., Hiebler S., and Himpel M. Complexing blends of polyacrylic acid- polyethylene glycol and poly(ethylene-coacrylic acid)-polyethylene glycol as shape stabilized phase change materials. Energy Convers. Manag., 64 (2012) 364-370.

[49] Mehling H., Günther E. Hiebler S., Cabeza L.F., and Castellón C., A New Measurement and Evaluation Method For DSC of PCM Samples, In: Proceedings of Effstock -11th International Conference on Energy Storage. Stockholm, Sweden (2009).

[50] Nikolić R., Marinović-Cincović M. Gadžurić S., and Zsigrai I., New materials for solar thermal storage - solid/liquid transitions in fatty acid esters. Sol. Energy Mater. Sol. Cells., 79 (2003) 285-292.

[51] Aydin A.A. and Okutan H. High-chain fatty acid esters of myristyl alcohol with even carbon number: Novel organic phase change materials for thermal energy storage-1. Sol. Energy Mater. Sol. Cells., 95 (2011) 2752-2762. 